Curry, D., Hammerschmid, G., Jilke, S., Van de Walle, S. (2015). Executive Perceptions of Public Sector Reform in Europe. In: Massey, A. \& Johnston, K. (eds). International Handbook of Public Administration and Governance. Cheltenham: Edward Elgar. Pp. 369-398.

\title{
The State and Perceptions of Public Sector Reform in Europe ${ }^{1}$
}

Dion Curry, Gerhard Hammerschmid, Sebastian Jilke, Steven Van de Walle

Like most other areas of the world, the public sector in Europe has undergone significant reform in the past two decades, shaped in part by a broader New Public Management (NPM) paradigm, but one that also introduces a unique European flavour to this form of public management. Whilst NPM and public administration in Europe shares similarities with other cases, the added complexity of differing starting points and the EU layer provide interesting insight into the nature of public administration. This chapter will draw on a large-scale survey of top European executives in central government, in order to develop a comprehensive picture of the perceptions of NPM reforms and their effects over the last five years. Focusing on a cross-selection of EU countries (plus Norway), ${ }^{2}$ the chapter will present findings about choice of policy instruments, relevance of different reform trends and their general success and impact within the case countries.

The chapter will first provide a general overview of the state of the public sector in the European countries under study before turning to how the public sector and its reform are perceived by top executives. This will focus on key trends in the public sector in terms of both NPM and post-NPM reforms, including usage of different policy instruments and the prevalence of trends regarding issues such as transparency, cooperation, digital/e-government, downsizing, red tape, citizen participation, contracting out and others. The chapter will look at the importance of these trends in the various case countries and across Europe before examining the nature of these reforms. Finally, the perceived success and overall impact of these reforms will be assessed, along with a brief examination of the impacts of the fiscal crisis on reforms in Europe. Throughout, the chapter will explore convergences and divergences in these issues across the European countries under study, before providing some conclusions about the state of the public sector, its reform and prospects for its future.

\section{The Public Sector in Europe: a General Overview}

The public sector in Europe has always drawn on a diverse set of starting points in terms of ideals, wealth and breadth. New Public Management-style reforms have also moved at different times, paces and extents through Europe. While the United Kingdom was at the forefront of such reforms, countries on the continent, especially in southern countries and the post-Communist states were slower to adopt change. In all countries, these changes came about through various combinations of necessity, innovation, ability and will. At the base of any reforms in Europe lies different and often competing traditions of public administration. Napoleonic traditions in many of the southern European countries (Ongaro, 2009) come from a very different starting point than the former

\footnotetext{
${ }^{1}$ The research leading to these results has received funding from the European Union's Seventh Framework Programme under grant agreement No. 266887 (Project COCOPS), Socio-economic Sciences \& Humanities.

${ }^{2}$ Austria, Estonia, France, Germany, Hungary, Italy, Netherlands, Norway, Spain, UK.
} 
Communist states in terms of both what the public sector should do and how it should do it. AngloSaxon and Scandinavian models also add to the mix. The EU has also acted to shape the nature of reform, especially through accession criteria for new member states. Reforms to these traditions have then been driven by political will or a lack thereof, with some countries having politicians with clear and distinct driving ambitions for the public sector, whereas in other countries reforms have been more piecemeal and less ideologically driven. Political will is often also shaped by the power of the trade unions representing the public sector, which in turn affects the nature and extent of reform. Finally, the economic boom of the 1990s and the current economic crisis have necessitated changes in direction and approach.

While classic NPM issues are still relevant to any discussion of the state of the public sector and its future reform, in recent years other factors have risen in importance. Questions of civic engagement through forms such as digital and e-governance have become more important with technological and ideational shifts (Dunleavy, Margetts, Bastow \& Tinkler, 2006). Hand-in-hand, there is more emphasis on making public management more transparent and accountable, potentially opening it to new public and private actors. At the same time, within the public sector, there has been an increasing prevalence of cooperation and collaboration in many different directions ( $O^{\prime}$ Leary \& Blomgren Bingham, 2009). A more bottom-up approach has been championed in some public sector approaches as either a positive way to engage governments and citizens 'on the ground', or as an attempt to download services and costs to lower levels of government. There has also been a consolidation of public services as a way of improving efficiency and streamlining public services. These factors all create a complex stew of factors that act differently in diverse country contexts to both drive and impede reform in European countries.

\section{$\underline{\text { The Case Countries }}$}

The case countries cover a broad swathe of European countries and provide a varied but detailed picture of how public sector reforms have taken root in different European contexts. They draw from countries of varying economic, social and political conditions, as well as covering both traditionally 'West' and 'East' countries, and both northern and southern blocs.

\begin{tabular}{ll|} 
& Case Countries \\
- Austria \\
- Estonia \\
- Germance \\
- Hungary \\
- Italy \\
- Netherlands \\
- Spain \\
\hline
\end{tabular}

Administrative reform in Austria has been an integral part of most government programmes over the last decades and frequently described as a never-ending story. The influx and rise of a more managerial agenda started in the late nineties (1989-1993) with a relatively comprehensive public 
management reform project that was later succeeded by administrative innovation programmes with a similar managerial emphasis (Hammerschmid \& Meyer 2005). These programmes included a commitment to efficiency and cost-saving, corporatisation, customer orientation, modern personnel management, management instruments and performance measurement mostly implemented in the form of small-scale projects. With a fundamental political change in 2000 that brought a nearly 60 year period of social-democratic government involvement to an end, public sector reforms strongly gained momentum. A large number of corporatisations, in addition to civil service system reforms and other restructuring of the machinery of government, played an important role in this phase, which culminated in a prominent "Austrian convent" (2003-2005) for fundamental state and administrative reform. However, this had only very modest outcomes in administrative practice. More recent years have been marked by far-reaching budgetary reform in 2007 and a strong egovernment agenda that has put Austria in a top position in the EU e-government benchmark. The budget reform resulted in a government-wide change towards outcome-based budgeting and accrual accounting, as well as other key elements of a performance management logic that came into force in 2013.

In Estonia, reforms started after the country regained its independence from the Soviet Union in 1991. There were three main three periods of public administration reform. In the first period after transition (1991-1996), broad reforms were carried out and privatisation, regulation and demonopolisation all occurred. In the lead-up to EU accession (1996-2004), more specific reforms took place to meet EU accession criteria and address issues such as transparency, accountability and accessibility of services. Post EU-accession (2004 to present), Estonian public service reform has been disjointed, although some NPM-style reforms have taken place, such as harmonising public and private working conditions. In general, Estonia has been amenable to NPM reforms, and regularly uses tools such as contracting out and performance-based indicators. It is also widely recognised for its e-government reforms (Savi \& Metsma, 2013).

In France, public service reforms have occurred slowly and have been relatively resistant to NPMstyle reforms (Rouban, 2008; Pollitt and Bouckaert, 2011). France's limited application and slow rollout of NPM public administration reforms in the 1980s and 1990s have given it a considerably different outlook on the role and values of public administration compared to other countries in the study. However, France's approach to public administration did evolve, but more incrementally and selectively than in other countries. This in part may be due to the Napoleonic traditions still valued in France, and the high degree of centralisation of the French state. In the 1980s, reforms in France first favoured decentralisation over efficiency or managerial reform, but did address some NPM issues such as service quality, user concerns and various management reforms. Throughout the 1990s, NPM policy instruments and tools were increasingly used in the French public service. The main reforms were in the area of budgetary processes, introducing tools such as programmeoriented budgets, an increased emphasis on performance management and new accountability measures. Under Sarkozy in 2007, there was also a General Public Policy Review intended to look at efficient use of objectives, instruments and implementation, again drawing from NPM-style ideas. The biggest reforms were seen to occur under Sarkozy's government. These reforms have altered the French public service, moving it away from Napoleonic ideas of centrality and uniformity and introducing more performance management techniques. In contrast, approaches such as agencification have occurred to a much lesser - and less systematic - extent in France (Bezes \& Jeannot, 2013). 
In Germany, public administration reform has been a recurring phenomenon made up of several different strands. While Germany originally espoused an idea of an 'active' state where state planning and intervention were seen as ways to drive further development, this shifted in the 1980s and 1990s to an NPM-like emphasis on a 'lean' state focused on privatisation and public sector downsizing. Since the late 1990s, this has again shifted to the idea of an 'activating' state built on engagement with all aspects of society to both guarantee public services at the state level, but also to engage with new ways of financing and delivering these services (Jann, 2003). These reforms closely mirrored NPM reforms until quite recently, with an emphasis on ideas such as better public management and structural streamlining. While many of the reforms have become more focused on NPM-type moves, Germany is considered to be a latecomer and at an early stage of building a true NPM-style system (Bouckaert and Halligan, 2008). These limited reforms are due to several factors. First, the federal nature of the German state limits the imposition of centralised administrative reforms. This is coupled with a decentralised power structure at the federal level involving many actors. Finally, an emphasis on stability and formalised processes has also helped to minimise sweeping reforms to the public sector. Recent reforms have now started to move towards newer post-NPM ideas such as transparency and network-based solutions (Pollitt and Bouckaert, 2011), but these are still very much an evolution of previous reforms, rather than a complete break into something new (Hammerschmid et al., 2013b).

Hungary has also significantly reformed its public administration since the fall of communism. A unitary state, it makes extensive use of both ministries and agencies, with the former largely responsible for policy-making and the latter responsible for implementing these policies. Since 1990, Hungary has undergone significant agencification, but these agencies largely lacked any overarching structural or legal framework until 2006, when a law was enacted that set out the basic requirements of these agencies as part of the larger government apparatus. Local governments were responsible for a large amount of public service delivery as well, but in 2011 many services, including health and education, were centralised. A combination of a strong legislature responsible for many executive functions, a high, $2 / 3$ vote threshold for the change of many laws, a strong system of checks and balances, a separate judicial administration and a strong network of ombudsmen created a system of 'regulatory impotence' (Hajnal, 2010) that placed limits on what policy makers could do. Wide-sweeping administrative change has been undertaken since 2010 when the Viktor Orbán government secured a $2 / 3$ majority in cabinet and thus was able to undertake significant reforms. These changes have removed many of the checks and balances that previously directed public administration in the country, and strengthened political and hierarchical control over most facets of administration, partly as a way of dealing with the financial crisis at the time. Ministries were overhauled and replaced by eight 'superministries', regional agencies have come under tighter central control, local government power has been reduced and bureaucratic recruitment is now controlled more hierarchically (Hajnal, 2013).

In Italy, the administrative systems and structures have been relatively unstable over the last twenty years. Instead, new and old structures have been introduced or changed in a sometimes overlapping fashion without improving stability in these structures. The administrative situation has also been affected by the changing political landscape, with centre-right and centre-left coalitions treating administrative needs differently, and the installation of a technical government in 2011/2012. Italy's attitudes towards Europe have altered the administrative landscape in both normal and austerityera politics and policy. Whilst the centre-left largely abided by EU standards, the centre-right 
coalition was more willing to break from these, but the debt crisis in the country has pushed EU institutions into playing a more prominent role in public management reform in the country. While Italy has long displayed some patterns of 'southern' public administration, such as clientelism and a certain absence of an administrative elite, reform in the early 1990s has allowed for the development of a more autonomous administrative body and the introduction of NPM-like ideas. Relations between government and the bureaucracy were brought more in line with the public sector in terms of employment conditions and performance management measures were introduced. Many reforms related to public service employment conditions, with further reforms increasing transparency of contracts and introducing further performance assessment measures. However, other issues have remained relatively unchanged, including political appointments to middle-level civil service positions and the centrality of trade unions in issues related to public service employment practices. Interestingly, NPM-style reforms have taken place in one policy area - health care - to a much greater extent than in any other policy area (Ongaro, et al., 2013).

In the Netherlands, the central government is mostly responsible for policy-making tasks, with executive and implementation tasks undertaken by agencies or local levels of government (although financed centrally). Dutch politics is consensual, and as a result ministries are relatively open to hearing external viewpoints from opposition parties, science and industry, but ministers retain ultimate responsibility for decisions. Although a unitary system, the Netherlands mostly avoids centralised government, and this is reflected in administrative reforms. For the most part, these reforms have aimed to slim down central government by decentralising more tasks to agencies and local levels. NPM-type reforms such as results-based budgeting and performance measurement have been used, with a move to private sector-like approaches being undertaken in the 1980s. This slowed in the 1990s due to an easing of financial pressures and a desire to return to the 'primacy of politics' (Pollitt and Bouckaert, 2011, p. 291). Under the second Balkenende government starting in 2003, reforms were also undertaken at the state level, focusing on quality of services, savings on overhead costs and reducing the administrative burden of governments (Van Twist, Van der Steen, Karré, Peeters, \& Van Ostaijen, 2009, p. 32). At the central level, there was also a push to reduce administrative burden and bureaucracy, improve organisation, clarify central government tasks and develop e-government approaches (Pollitt \& Bouckaert, 2011, p. 296). While efficiency was a goal of this reform, it was more focused on reducing budgets and not on reducing the size of the civil service. Since 2007, reforms have focused on the central level of government, again looking to improve efficiency by promoting cooperation between departments and reducing fragmentation, but now also by reducing staff (Luts et al., 2008, p. 41; Van de Walle, Jilke \& van Delft, 2013).

Norway has a large civil service due mainly to its universal welfare state, and trust in government has been high while the effects of the financial crisis have been small. While it is a unitary state, there is some political and administrative decentralisation. There are two ministerial levels in the country, with relatively powerful sectoral ministries and weaker supra-ministries that mainly play a coordination role between ministries (Christensen, 2003). There is a strong local level of government, and this level both develops and implements local-level policy and implements centrally-decided policy. While economic strength and political and administrative culture have largely dampened the effects of NPM reforms in Norway, some changes have occurred in line with international waves of NPM reform. In the mid-1980s there were moves to reform the central level along some NPM-style lines, with more reform in the 1990s under pressure from the OECD to pursue further change. However, these reforms have not been consistent over time and tend to be 
piecemeal in nature. They have focused mainly on efficiency aspects within the public administration and have largely avoided other reforms such as privatisation or downsizing the state. There has also been a shift towards developing more autonomous agencies, with a move since the 1990s to creating more autonomous state-owned companies in many sectors, along with a greater focus on NPM reforms within these bodies, such as performance measurement and results-based budgeting. While these changes have increased vertical coordination, there is little horizontal coordination across sectors. In addition, the current government has attempted to roll back some of these NPM reforms. However, there is disagreement within the governing coalition about the state of the administration, resulting in a rebalancing rather than transformation of NPM reforms already implemented. This has created a layered and hybridised form of public administration combining old and new ideas (Christensen, Lie and Lægreid 2007; Christensen and Lægreid 2011; Lægreid, Dyrnes Nord $\varnothing$ and Rykkja, 2013).

Public administration reform in Spain has been undertaken both to get rid of Franco-style public administration ideals and also as an attempt to modernise the public sector. Starting from a broad Napoleonic tradition, Spanish reform in the late 1970s focused on reducing bureaucracy and red tape by reorganising administrative and ministerial bodies. In the 1980s, the focus shifted to decentralisation with the creation of regional governments and regulation of local governments. A greater emphasis was placed on modernisation in the 1990s as a way to improve relations between the administration and citizens. This included NPM-type ideas such as treating the citizen as a customer, streamlining administrative procedures and increasing the focus on efficiency, effectiveness and quality of services. However, there was some resistance from senior executives to certain NPM objectives such as managerial autonomy, management by objectives and a resultsbased focus, which limited the actual reform that took place in the country. Since the late 1990s, Spain has had a clear reform agenda with an NPM focus, aiming for a flexible and efficient organisational structure, reform of administrative courts, new regulatory frameworks for recruitment, efficiency and quality in service delivery, and the incorporation of new technology in the process (Torres and Pina, 2004). Other post-NPM reforms have started to appear in the 2000s, such as efforts to improve transparency and cooperation and collaboration among different public bodies. Since the crisis, most reforms have been driven by budgetary restrictions (Alonso and Clifton, 2013).

Finally, public administration reform has been a persistent theme in the United Kingdom, albeit one that ebbs and flows. The extent of changes and the focus on many private-sector ideals in public administration have generally led to the UK being seen as the 'purest' and most extensive form of NPM in Europe. While this is true, the differences between the UK example and other European cases should not be overstated (Pollitt and Bouckaert, 2011). After the establishment of the welfare state and a gradual professionalization of the civil service, in the 1970s the focus moved to improving efficiency and effectiveness of public institutions, including a drastic reorganisation and reduction of local governments in 1974. After the economic crises of the 1970s and the election of Thatcher in 1979, significant NPM-style reform of the public sector was undertaken. Key goals were to reduce the size of the public sector, open it to market forces and run it more like a private-sector business. The civil service, previously under its own department, was put under control of the Treasury and business-like arrangements such as target-based management and, in some cases, performance-based pay were introduced. Compulsory competitive tendering was launched at the local level along with further competition in providing public services. Tony Blair's election in 1997 
marked the beginning of a 'Third Way' approach of balancing the market, state and civil society in providing services. This approach retained business-inspired ideas such as performance measures and contracting out, whilst attempting to balance this with a top-down focus on continuous improvement and targets-based planning, along with a post-NPM aim to strengthen relationships and coordination between the various actors in delivering public services. This Third Way approach left a public service driven largely by market and NPM-style public administration coupled with a wilful effort to 'steer' the management of these disparate actors at the central governmental level. Since the election of the Conservative/Liberal-Democrat coalition in 2010, the focus of public administration reform has been clearly on reducing costs and the size of the public sector (Andrews, Downe \& Guarneros-Meza, 2013).

\section{Factors Affecting Reform: Goal Ambiguity and Public Sector Autonomy}

The Survey

A 31 question survey was sent electronically or via post to over 21,000 high-ranking civil servants in 10 European countries. The survey's aim was threefold: (1) to capture perceptions on the current status of management, coordination and administration reforms; (2) gauge the effects of NPM-style reforms on performance, values/identities, coordination and social cohesions; and (3) to examine the impact of the financial crisis on public administration. The survey was sent to the entire population of top and medium-high level civil servants in each country, translated into each countries national language. The overall response rate for the survey was $23.7 \%$, with individual country response rates varying from $11.4 \%$ (UK) to $36.5 \%$ (Austria). While the overall response rate is somewhat low, it is consistent with other surveys of executives and in each country there were at least 300 responses recorded, with a total number of responses of $4814 .^{3}$

As outlined above, many factors affect the ability of public sector reform to be introduced, and in turn the success of these reforms hinges on the ability for them to be undertaken in an effective manner by the public service. Two factors that have an impact on how easily reforms are implemented are the nature of the goals of reform and the autonomy of the public sector in implementing technical changes without political interference.

\section{Goal Ambiguity}

Reforms to performance management are best executed when goals are limited, clearly state and communicated, and easy to observe and measure (Rainy, Jung 2010). In looking at clarity of goals based on these three factors, all the countries studied showed a relatively uniform slightly negative view of how measurable and well-defined results and objectives were. While several countries (Germany and France) proved to think somewhat more favourably about the clarity of goals and others more negatively (United Kingdom, the Netherlands), overall perceptions in all countries were on the negative side of the scale. In general, managers of agencies reported less goal ambiguity than

\footnotetext{
${ }^{3}$ For a more detailed outline of the survey methodology and process, please see Hammerschmid, Oprisor and Štimac, 2013.
} 
managers in ministries. While this lack of clarity was seen as a challenge, it nonetheless was not perceived to be a barrier to introducing NPM-style tools into public sector practices. ${ }^{4}$

Figure 1: Perceived goal ambiguity and measurability (aggregate mean for several items per country; 1= low goal ambiguity, 7=high goal ambiguity)

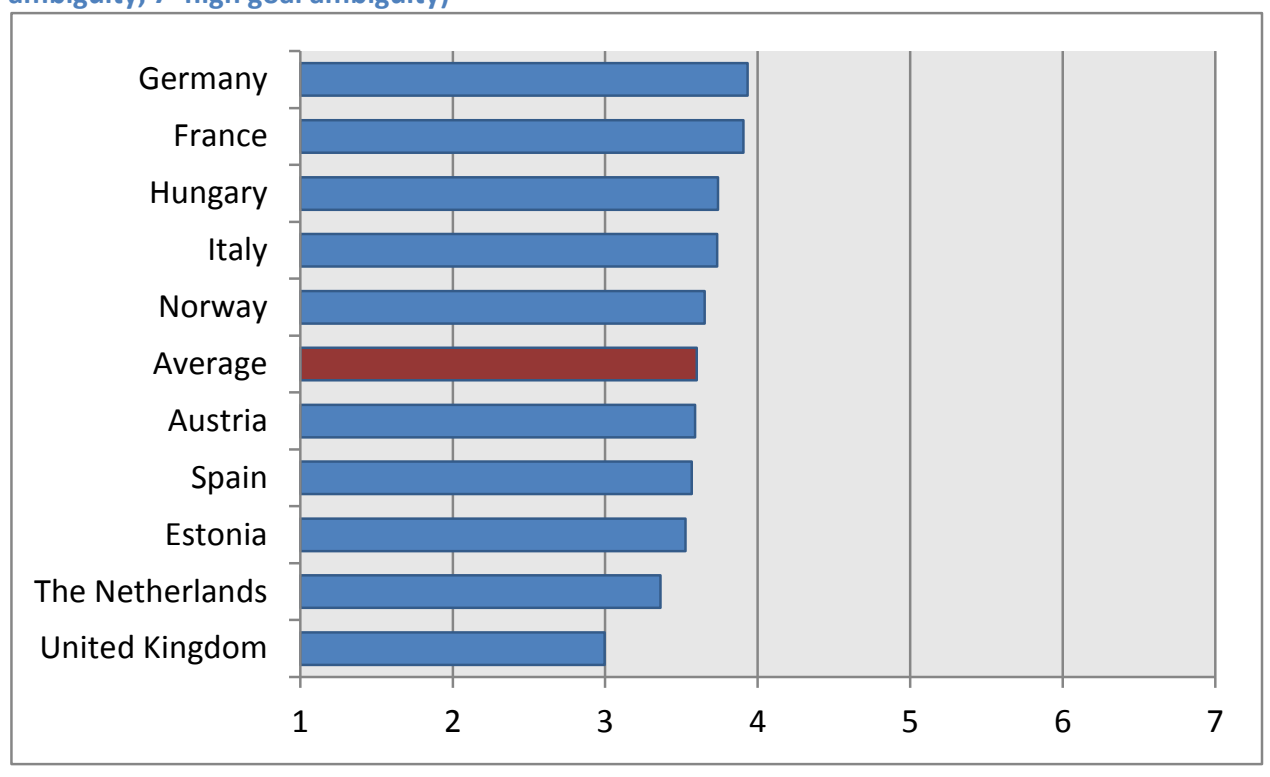

There was some variation between countries. Spanish executives tended to feel more negatively than the average about the clarity of their goals and how they are stated to staff. Germany overall had a relatively high view of goal ambiguity, but there was significant difference in types of ambiguity. In terms of whether their activities were easy to observe and measure, over half felt their activities were not clear. They had a much more favourable view of whether their goals are clearly stated and are clearly communicated to staff, where over half felt that these issues were not ambiguous. To the same but lesser extents, Norway and the Netherlands displayed a comparable split, where both felt that goals were clearly stated but it was not so easy to observe and measure activities related to these goals. The UK had the lowest perceived goal ambiguity by a significant margin. Executives strongly felt that goals were clear and clearly communicated to staff. However, a majority of UK executives also felt that the number of goals was high and not easily measured or assessed, painting a slightly more complicated picture as regards goal ambiguity. Interestingly, the results in Italy were highly sector-dependent. In general, Italian executives felt that goals were clearly stated and communicated, but not as easy to observe or measure. This was profoundly different and opposite for those working in the health sector, who felt that it was easy to observe and measure their activities but that these goals were not clearly stated or communicated (Ongaro et al., 2013).

\section{Autonomy of the Public Sector}

The autonomy of the public sector vis-à-vis political institutions also has an impact on the nature and quality of reform. Autonomy consists of both managerial autonomy (the ability to make organisational and structural changes, as well as decisions on personnel, budget and contracting out) as well as policy autonomy (over how to design, decide on and implement policies), and the extent

\footnotetext{
${ }^{4}$ See Hammerschmid, Oprisor and Štimac, 2013 and Hammerschmid et al. (2013a) for a more detailed description of scales and questions.
} 
to which public sector institutions can make technical decisions free from political interference will have an effect on reform. While some country executives felt they had a high degree of autonomy (the Netherlands), others felt a low degree of autonomy to manage or make decisions freely (Italy).

Figure 2: Perceived degree of management and policy autonomy (aggregate mean for several items per country; 1=very low autonomy, $7=$ very high autonomy)

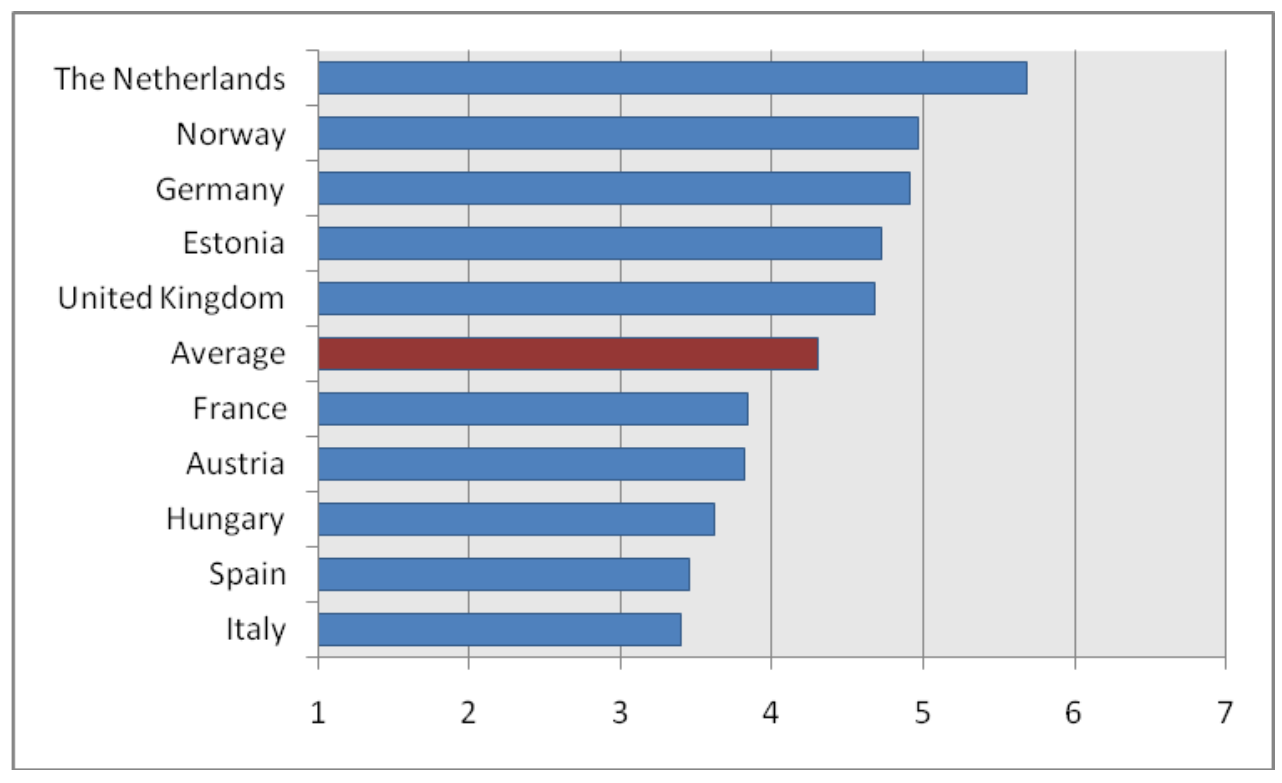

In different countries, different types of autonomy were noted as being either stronger or weaker by public sector executives. For instance, in the UK, all forms of autonomy were perceived as higher than average, but especially in allocating budgets, organisational structuring and implementation of policies. Autonomy of the public sector in the Netherlands was perceived as high, and this applied across the board. Autonomy was seen to be highest in managerial tasks and implementing policy, but even in designing and choosing policies, executives were mostly positive about their levels of autonomy. In Norway executives perceived higher levels of autonomy in managerial issues such as hiring staff or organisational structure, as well as policy implementation. However, they felt they had lower autonomy in contracting out or choosing or designing policies. Estonian executives perceived a high degree of autonomy in making personnel decisions and implementing policy, but a much lower level in terms of structuring the organisation or contracting out services. This was similar in Hungary, where the lowest level of autonomy was felt in contracting out services, and the highest level in implementing policies. Interestingly, in Germany executives felt they had more autonomy in choosing and designing policies compared to implementing these policies. While their autonomy in choosing and designing policies was perceived as significantly higher than average in the European countries studied, their control over implementing the policies was actually lower (Hammerschmid et al., 2013b).

In France, in contrast, where perceptions of autonomy were below average, civil servants felt they had very little autonomy over recruitment, budgeting decisions and, especially, getting rid of staff. On the policy side, French executives felt little autonomy in deciding on public policy decisions, but more autonomy in implementing them. Different groups of executives also felt different levels of control. While agency directors reported a high level of autonomy, directors of inter-ministerial units at the départemental level felt they had little autonomy in most areas (Bezes and Jeannot, 2013). 
Autonomy was perceived as particularly low in Italy and Spain. In Spain, executives felt they had a low level of autonomy almost across the board in both policy and managerial senses. Spanish results were well below the European average in choosing and designing policies, implementing policies, organisational structures, contracting out, allocating budgets, and is particularly low in promoting, hiring or removing staff. Italian executives had little autonomy over managerial decisions such as hiring and dismissing staff, partly due to a heavily unionised public sector, but on other measures of autonomy - budget reallocation, contracting out, organizational and structural design and effecting policy formulation and implementations - Italian executives felt they had a higher level of autonomy than the European average. There was a significant sectoral difference in Italy, with those in the health care sector feeling they had significantly greater autonomy across the board. Overall, though, Italian executive autonomy was well below the European average (Ongaro et al., 2013).

In addition to the degree of autonomy, another indicator of managers' freedom in reform is the degree of politicization of the public sector. This includes questions of whether politicians respect the technical expertise of the administration, whether politicians try to influence senior-level appointments and whether politicians interfere in routine activities. When aggregated, these factors of politicization show some variation across Europe (Hammerschmid et al., 2013a).

Figure 3: Perceived degree of politicization (aggregate mean per country; 1=low degree of politicization, 7=high degree of politicization)

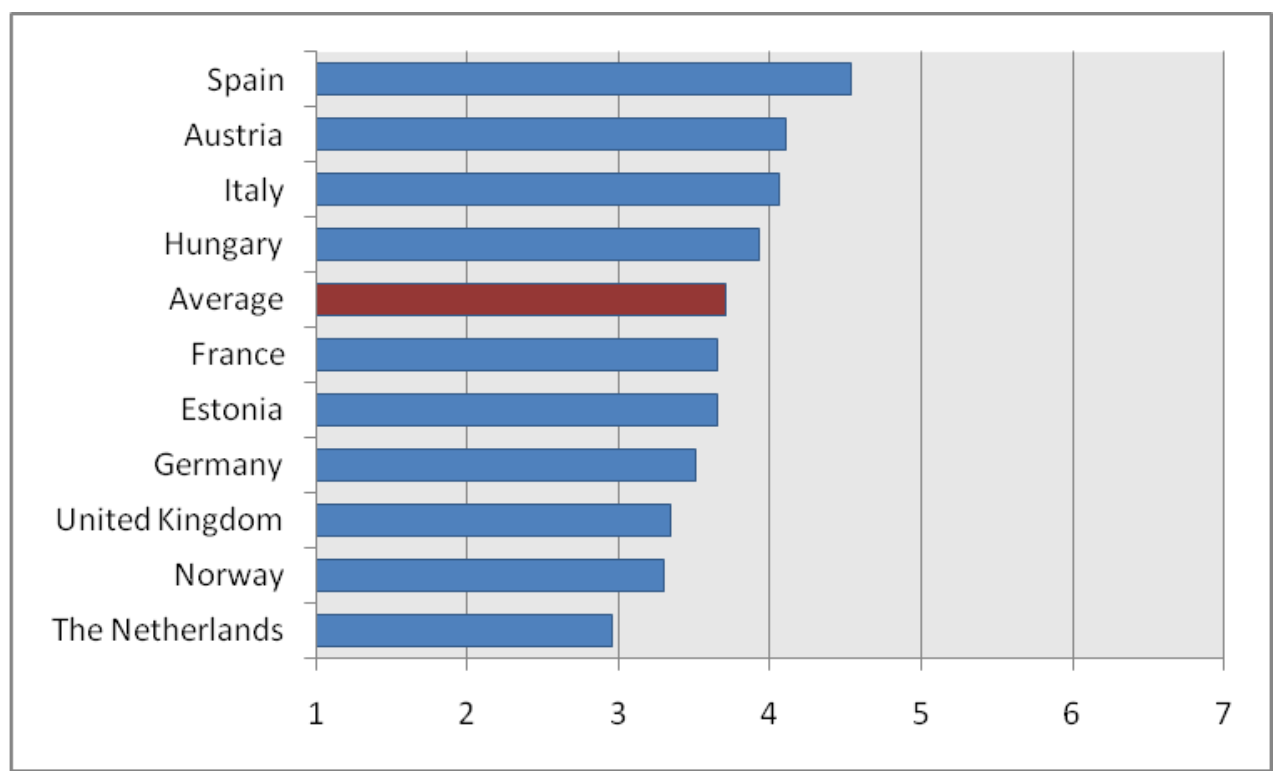

This graph shows that, unsurprisingly, those administrators who felt they had more autonomy also faced a lower degree of politicization of the administration. In general, agency executives felt more autonomy than their ministry counterparts. In country differences, Estonia was found to have a relatively low level of politicization of the public sector, which is in line with previous research that shows that Estonia has among the lowest level of political interference in the civil service among the new central and Eastern European EU countries (Meyer-Sahling, 2011). As a new democracy, the political parties in the country have not yet developed the capacity to steer public administration or become overly involved, and the small size of the country also means that there is less capacity to develop overlapping political and bureaucratic functions (Randma-Liiv, 2002). Executives in Norway also had a relatively positive perception of their autonomy, particularly in regard to the respect 
politicians have for the technical expertise of the administration, which was significantly higher than the European average.

In contrast, Germany had a relatively high level of politicization, although executives did feel that politicians respected their technical expertise. Also, while they did feel that there was a high degree of politicization, only a minority felt that better policy would be produced if moved out of the political realm. This was significantly lower than the majority average in other countries. Italy showed significant difference from the European average in perceptions about how much influence politicians should have over the process, strongly feeling that policies will be improved if they are removed from politics. Hand-in-hand, there is a much higher perception in Italy that senior executives, rather than politicians, are the ones that should initiate reforms or new policies. Spanish executives had the highest perceptions of political interference, especially in influencing senior-level appointments and in instigating reforms, but executives generally do not feel that politicians interfere with day-to-day activities. However, the results are particularly lower than the European average in terms of respect of technical expertise and the politicization of senior-level appointments.

\section{Key Trends in European Public Sector Reform}

As the cases analysed as part of the survey were diverse, it is interesting to note both the similarities and differences that present themselves when considering policy reform across national contexts. A traditional idea of NPM encompasses several factors that should be present, including such things as performance measurement, results-oriented activity and others. In addition, in recent years postNPM ideas such as transparency, e-government and collaboration have also begun to take root in different national contexts. The effectiveness of these different facets of NPM and post-NPM reforms were evaluated by top public executives and provide insight into how well NPM is performing - and has taken hold - in various countries and Europe as a whole. It also provides an understanding of whether these NPM reforms have been supplanted by post-NPM ideas in the minds of executives when implementing reforms.

The next three parts of this chapter will examine the perceptions of reform held by top public executives over the last five years. First, it will examine the perceptions on the necessity and importance of these reforms, before turning to look at the nature of these changes in terms of their approach. Finally, assessments of the success of these reforms will be examined. General trends can be observed, but specific examples will also be drawn from the case countries.

\section{Necessity and Importance of Different Types of Reform}

Public administration reform trends can aim to address different issues and have very different goals and trajectories. While traditional NPM reforms focus on issues such as contracting out, privatisation and performance management, post-NPM reform areas have placed greater emphasis on factors such as coordination and cooperation, transparency and citizen participation. After twenty years of NPM being in the public eye, perceptions of NPM-style reforms still differ on whether these reforms are, in fact necessary, and how important they are. As mentioned above, the focus of public administration over the last twenty years has also shifted and now often incorporates post-NPM ideas as well. 
The results of the survey are revealing in showing an increased importance placed on post-NPM reforms, while many NPM-style changes have lost relevance. More emphasis has been placed in recent years on ideas such as network governance, digital and e-governance, transparency, accountability and citizen engagement. Interestingly, but perhaps not surprisingly, NPM-style reforms were seen by executives as less important than newer emerging, 'social'-related trends such as e-government, collaboration between public sector actors and transparent government. Overall, NPM reforms are seen as less important on average across all countries, while participatory and citizen-oriented approaches are seen as more relevant. These reforms were generally viewed as less important in countries such as Hungary and France (except for public sector downsizing in France), whereas the UK, Estonia and the Netherlands placed much more importance on most if not all reforms.

Figure 4: Importance of reform trends (Q: How important are the following reform trends in your policy area?; 1=Not at all, 7=To a large extent), graph depicts overall average plus highest/lowest country average; the solid line indicates the average for all reform trends

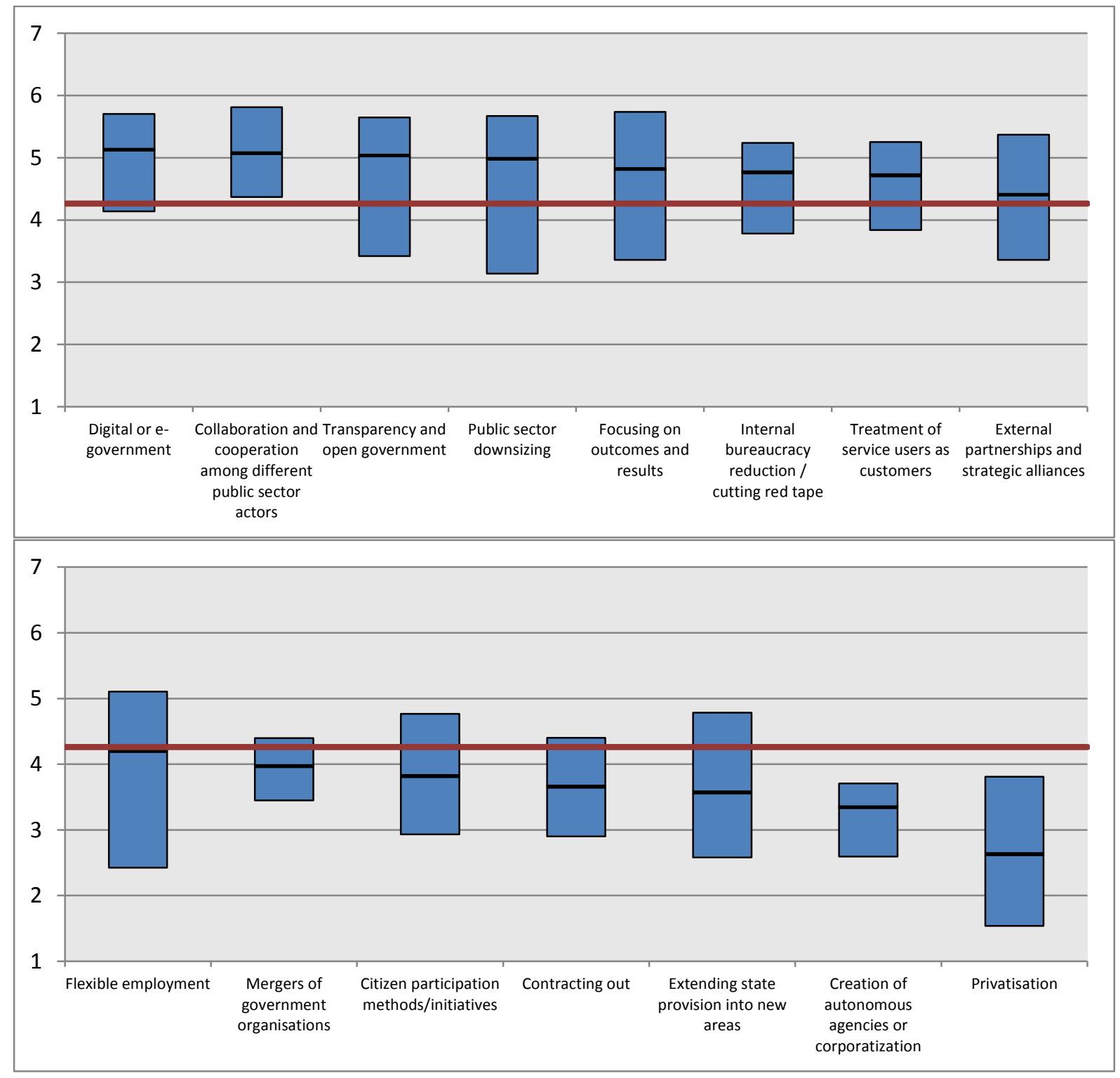


In certain areas there was significant variation between countries. This was especially true in looking at public sector downsizing, a significantly important consideration in a country such as the UK, France, Estonia and the Netherlands, but least important in Norway, where they rated it a full point less important than the next lowest country (Italy). There was also a large difference in how important a focus on outcomes and results was in each country, with it being much more important in countries like the UK and the Netherlands but less important in Spain, France and Italy. Flexible employment, privatisation and transparency and open government also see significant cross-country variation. Meanwhile, issues such as transparency and open government are important throughout, although France remains somewhat of an outlier, rating it as much less important than other countries. Digital/e-government, collaboration/cooperation among public sector actors and customer orientation are all seen as important and show comparative consistency across countries.

In specific countries, there was also some variation in the ordering of importance of these trends, although some countries were close to the European average. Norwegian officials are mostly in line with general trends and tend to favour post-NPM reforms, often to a greater extent than the average. Transparent and open government and e-government are seen as most pertinent, but a focus on outcomes and results is also seen as important. Although they saw collaboration and cooperation among different public actors as important, this was not reflected as clearly in actual practice, as vertical coordination is strong but horizontal coordination remains weak in Norway (Fimreite and Lægreid 2009). The largest differences between Norway and the rest of the Europe were in the area of public-sector downsizing, where only $25 \%$ of Norwegian executives saw this as important compared to $70 \%$ of the overall population (Lægreid, Dyrnes Nord $\varnothing$ and Rykkja, 2013).

The Netherlands shows a mix in perceived importance between NPM and post-NPM reform trends. Collaboration and cooperation and transparency and open government are both seen as highly important, as is a focus on outcome and results. Privatisation was seen to be the least important reform factor, along with agencification. Although the country had in the past pursued these strategies, these are now seen as less important. In the UK, a focus on outcomes and results, public sector downsizing, e-government, transparency and external partnerships all received high scores in terms of importance. Privatisation, agencification and the extension of state provision were deemed the least important in terms of reform. Transparency and open government and development of external partnerships were more important in the UK than in Europe on average, while the extension of state provision was lower than average.

In Germany, NPM-style reform trends are not seen as overly important, with a majority finding reforms such as privatisation, contracting out and agencification to be of low importance in the country. However, some NPM-related trends were seen to be more relevant, with downsizing perceived as the most important, followed by a focus on outcomes and results and the cutting of red tape. Post NPM trends such as e-government, customer orientation and transparency and open government were all seen as important by a majority of executives. Interestingly, within the sample public sector executives in ministries perceived significantly higher levels of downsizing and lower levels of contracting out than their agency-based peers. In general, the German case was in line with other European countries, though, which belies the conception of Germany as lagging behind other countries in terms of public sector reform (Hammerschmid et al., 2013b). 
French executives had a much different perception on NPM reforms than other countries in many areas. Transparency, open government and citizen participation, along with flexible employment, contracting out and external partnerships were all seen as relatively unimportant. While the relevance of downsizing measures and organisational mergers were seen as high, this was not equated to privatisation, where only $9 \%$ of executives felt this was highly relevant. Hungarian executives saw very little relevance in many NPM-style reforms, most notably privatisation, but also agencification and contracting out. However, downsizing was seen as one of the most relevant types of reform, along with a focus on citizens as customers. The importance of NPM reforms was also somewhat less developed in Spain, especially as regards agencification and customer orientation, which were lower than the European average. The reforms seen as most important were public sector downsizing, e-government and transparent and open government.

In Italy, the perceptions of importance of various reform trends were quite different to actual government priorities in these areas. Executives perceived that e-government, enhancing transparency and open government and citizen participation were important reform initiatives, but these had not been singled out at the governmental level. The importance of privatisation and contracting out were also significantly higher in Italy than in Europe on average. This was even higher in the health sector, showing that NPM-style reforms have probably hit that sector the most (Ongaro et al., 2013).

\section{The Nature of Reform}

Overall views on the success of reform are obviously important, but so too is determining how the nature of specific aspects of the reforms were perceived. Executives were asked their perceptions of reform based on ten different scales.

\section{Public Sector Reforms in My Policy Area Tend to Be....}

\begin{tabular}{l} 
Too Demanding \\
Unsuccessful \\
No Public Involvement \\
About Cost-Cutting \& Savings \\
Contested by Unions \\
Substantial \\
Crisis and Incident Driven \\
Driven by Politicians \\
Comprehensive \\
Consistent \\
Top Down \\
\hline
\end{tabular}

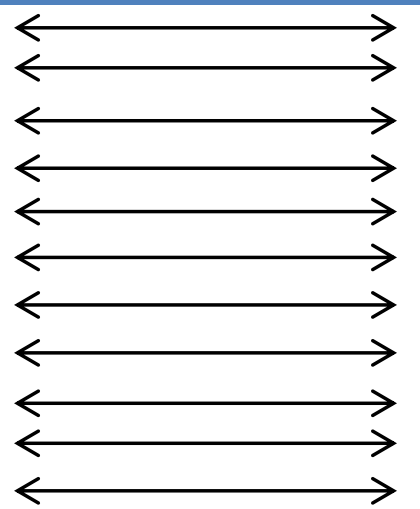

Not Demanding Enough

Successful

High Public Involvement

About Service Improvement

Supported by Unions

Symbolic

Planned

Driven by Senior Executives

Partial

Inconsistent

Bottom Up

While some factors - such as top down reform and an emphasis on cost-cutting and savings - were seen in nearly every country, differences were noted in some countries as well. Executives in Norway tended to have a more positive view of reforms across the spectrum, seeing them as more consistent, comprehensive and substantial than the average. In addition, they saw them as more bottom-up, less contested by unions and more open to public involvement. The situation was more negative in France, where most executives felt the reforms were too demanding, contested by the unions, driven by the crisis and mainly not driven by public opinion. In Germany, more public sector executives than the European average felt reforms were not demanding enough, which fits with 
previous research on Germany's incremental approach to policy change. This is also supported when compared to results in other countries. German executives perceived reforms to be more inconsistent, partial and symbolic than other countries, indicating more reticence to fast reform (Hammerschmid et al., 2013b). However, perceptions of success of these reforms was quite similar in Germany compared to other countries.

Several of these factors deserve to be singled out. Executives in all ten countries were asked, in general, not just how successful public sector reform was, but also whether the reform was too demanding, or not demanding enough. On these two factors, there was little cross-country consensus or clear pattern, as the groups cut across traditional north/south and east/west divides. This suggests an uncoupling between types of reform undertaken (which more closely mirror traditional groupings) and perceptions of whether these reforms were undertaken in an appropriate manner.

There was significantly more consensus between countries on whether the reforms were about cutting costs or improving services, but more variance on whether these reforms had been successful or unsuccessful. Spanish executives were an extreme case in feeling that the reforms were clearly about cost-cutting but mostly unsuccessful. In general, respondents in that country were three times more likely to perceive reforms as unsuccessful than successful. On the other side, Norwegian executives not only felt that reforms were mostly successful, but also felt that these reforms were more about improving services than cutting costs.

Executives were also questioned about whether the reforms were conducted from the top down or from the bottom up. Here, no countries surveyed felt that the reforms were conducted from the bottom up, and no clear pattern connected the top down reforms with level of success. There were also few cases where executives felt that the reforms were conducted with significant public involvement, except for in Hungary and Norway. The data gave slight indication that reforms that involved the public were seen to be moderately more successful though (Hammerschmid et al., 2013).

\section{Success of Reforms}

\section{Overall Impact}

Of course, these reforms are aimed at improving the general situation of public administration in the case countries. After assessing the importance given to different facets of reform that public administration executives have felt over the past five years, and the nature and reasoning behind these reforms, we now look at whether these reforms were perceived to be effective and successful.

Public executives were asked overall whether they had a positive or negative opinion of the situation of public administration in their country compared to five years ago. Here, there is significant variance between countries in whether their assessment of public administration had improved or deteriorated.

Figure 5: Overall PA assessment (Q: Compared with five years ago, how would you say things have developed when it comes to the way public administration runs in your country?) 


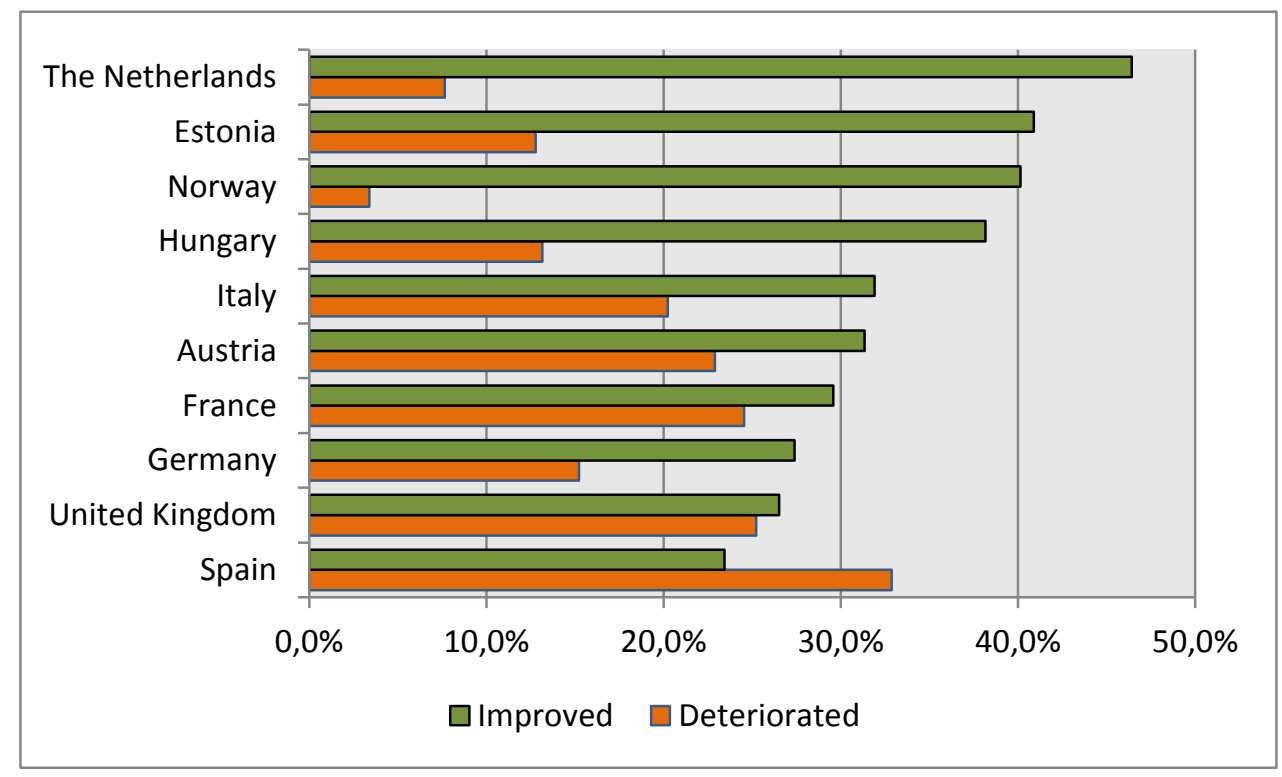

Spain was the only country where more respondents felt that the situation had deteriorated more than improved. Views were decidedly mixed in countries like France and the United Kingdom, whereas Norway, Estonia, Hungary and the Netherlands all had high perceptions of improvement and low perceptions of deterioration. Perceptions of improvement/deterioration were measured in all ten countries on 15 different factors, covering both such in managerial aspects and success in policy aspects.

Figure 6: Different performance dimensions (Q: Thinking about your policy area over the last five years how would you rate the way public administration has performed on the following dimensions?; 1=Deteriorated significantly, 7=Improved significantly) 


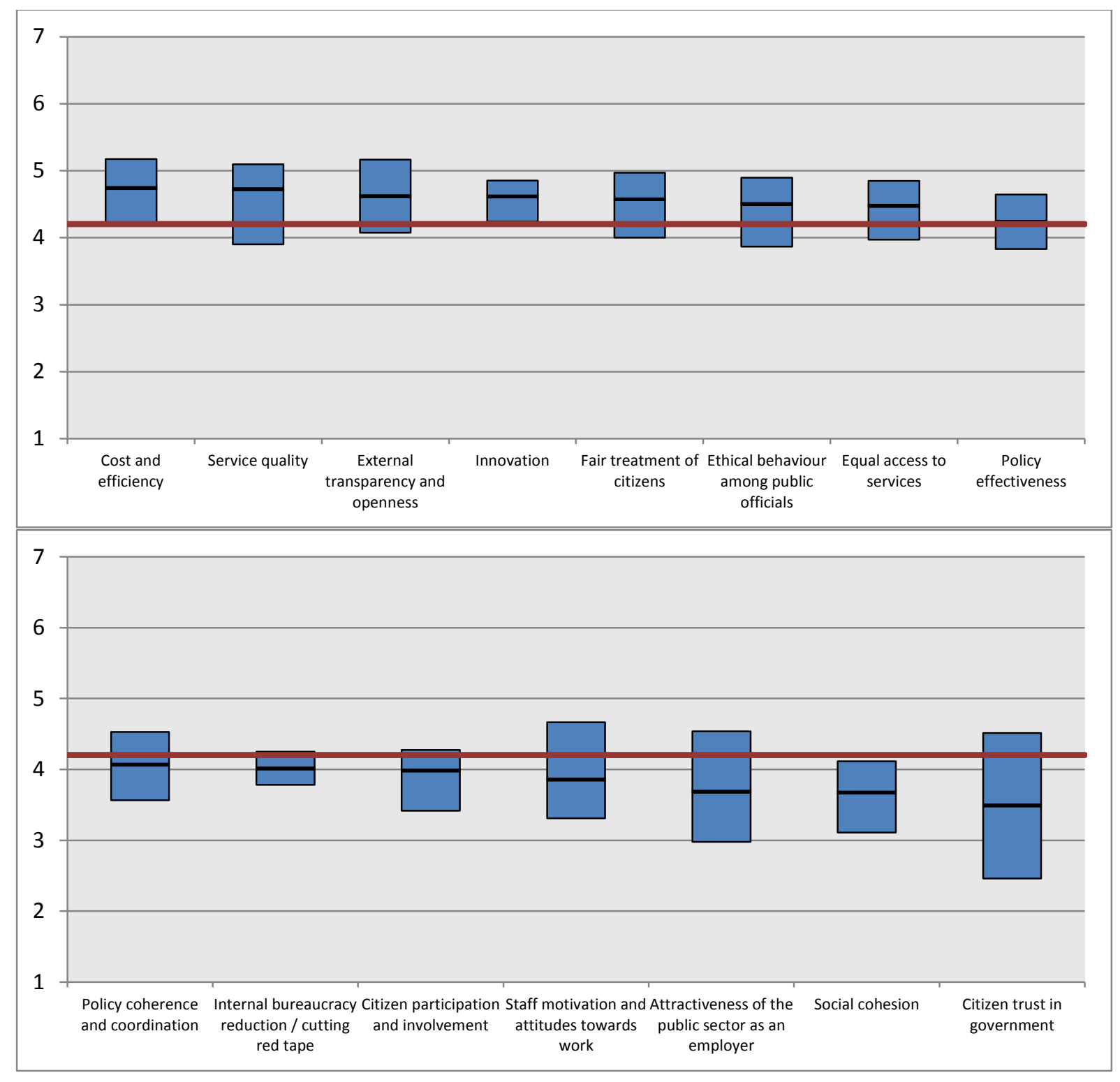

Speaking generally, there was not significant variation from country-to-country in many of these aspects. There was a perception that factors such as cost and efficiency, service quality and innovation all improved slightly, as did external transparency and openness, fair treatment of citizens and ethical behaviour among public officials. In contrast, there were perceptions of a slight deterioration in areas such as social cohesion, staff motivation and attractiveness of the public sector as an employer. Citizen trust in government was seen, on average, to be the aspect that had most deteriorated from five years ago. In certain issues such as internal bureaucracy reduction/cutting red tape and innovation, there was little variation between countries in their assessment of these characteristics. In other areas, most noticeably citizen trust in government, but also in attractiveness of the public sector as an employer and staff motivation and attitudes towards work, there was more variation between countries in the relative success/deterioration in these qualities.

Cost and efficiency was the most positively assessed outcome of public sector reforms overall, with all countries reporting a generally positive assessment compared to five years ago. The United Kingdom and the Netherlands assessed this most positively, with Germany, Norway and Austria also 
having an above average view of success in this area. In contrast, Spain was the country that reported least success in this area, although even there the assessment was generally positive.

Figure 7: Cost and efficiency ( $Q$ : Thinking about your policy area over the last five years how would you rate the way public administration has performed on the dimension: cost and efficiency?; 1=Deteriorated significantly, 7=Improved significantly)

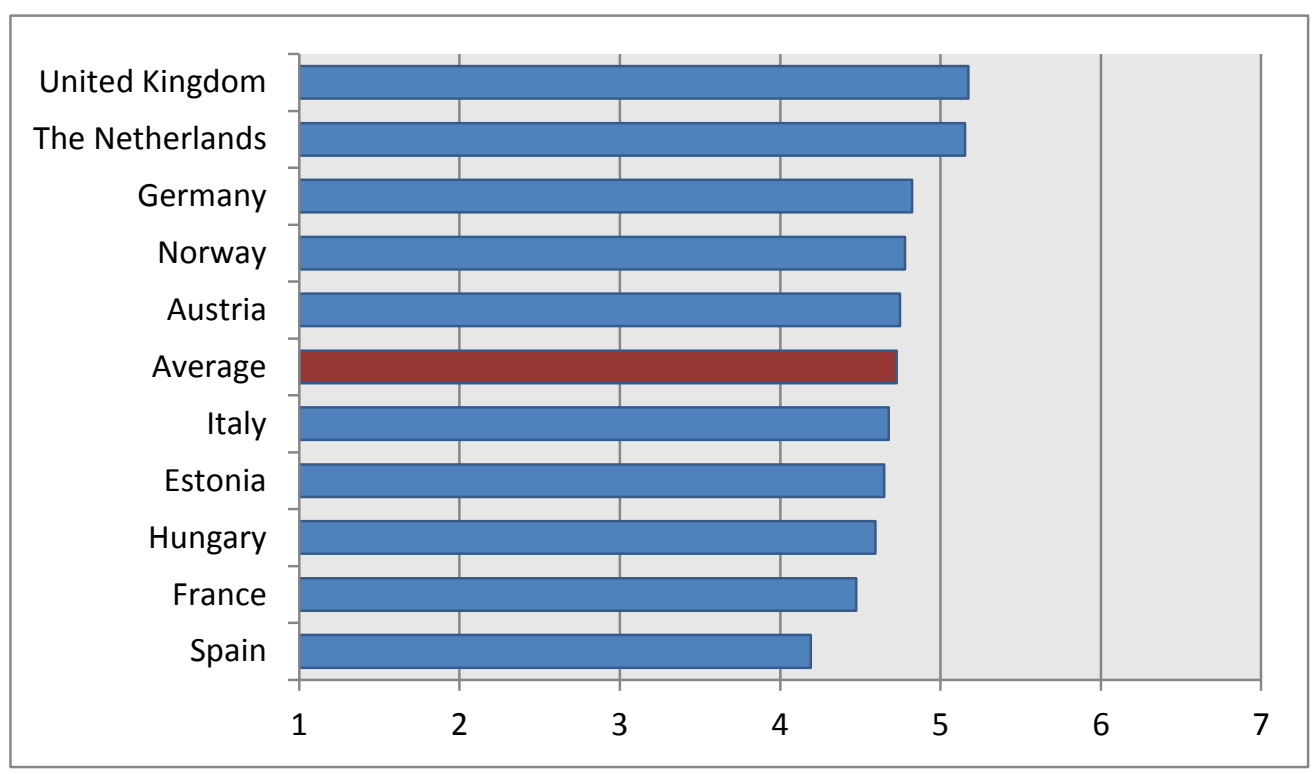

On the other end of the spectrum, citizen trust in government was seen as the least successful outcome of reform trends. This trend also showed significant variation between countries. Norway was the only country to feel that citizen trust had modestly improved in the past five years, with all other countries feeling that it had deteriorated. By some margin, Spain was the country who felt this had deteriorated the most, with France, Italy and the United Kingdom also having fairly pessimistic views of citizen trust compared to five years ago.

Figure 8: Citizen trust in government (Q: Thinking about your policy area over the last five years how would you rate the way public administration has performed on the dimension: citizen trust in government?; 1=Deteriorated significantly, 7=Improved significantly)

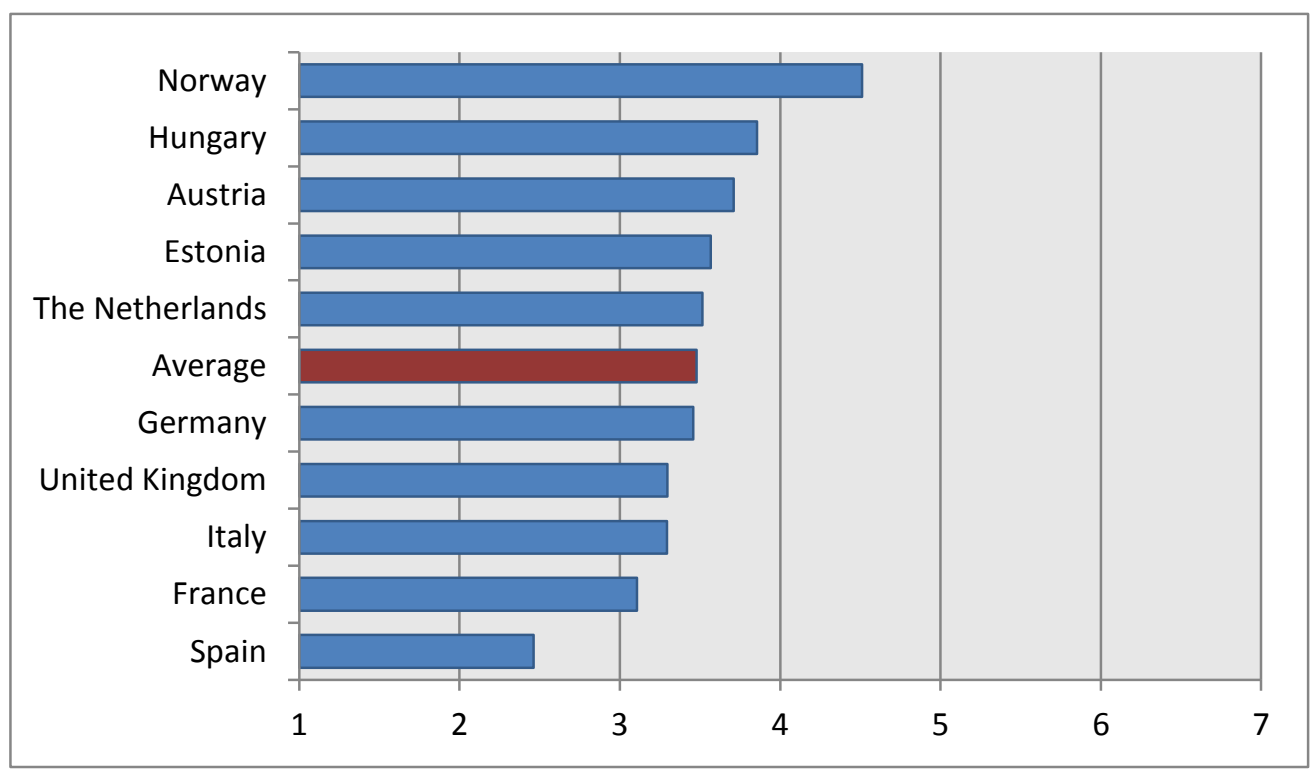


A few other employment-related factors were measured in all countries. Job satisfaction was moderately high in all cases (more positive than negative), being highest in Norway, the Netherlands, the United Kingdom and Italy. Organisational commitment showed that in all countries executives felt more committed to their organisation than not. Commitment was especially high in Hungary and Italy, and lowest (but still positive) in Norway and the Netherlands. On the other hand, work stress showed fairly significant country variation. Stress was perceived as high in Spain (more stressful than not), while all other countries found their job to be less stressful than stressful. Stress levels were particularly low in Austria and Germany.

Each country had slightly different areas in which they felt there was the most improvement. Situations were generally felt to have improved in almost all areas in Norway, especially in service quality, cost and efficiency and innovation. Only in internal bureaucracy reduction/cutting of red tape was there a relatively strong feeling that things had deteriorated, but even here a larger proportion felt that it had improved. Results were significantly more positive in all areas apart from innovation when compared to the overall European perception, with service quality, transparency and citizen trust in government showing the biggest gap between Norway and the rest of Europe (Lægreid, Dyrnes Nord $\varnothing$ and Rykkja, 2013).

In Estonia, fair treatment of citizens, equal access to services and social cohesion were perceived to have improved more than in other European countries. Ministerial executives found more improvement in policy effectiveness and policy coherence and coordination, while at the agency level, equal access to services and fair treatment of citizens were seen as the areas in which things were better than five years ago (Savi \& Metsma, 2013). Improvements in the UK were mostly perceived in managerial functions such as cost efficiency, innovation, service quality and policy effectiveness, while citizens' trust in government and attractiveness of the public sector as an employer were seen to have deteriorated by a majority of respondents.

Dutch perceptions seem to have been shaped by recent issues in that country, with citizen trust in government and ethical behaviour among public officials rated rather low, corresponding to Dutch media stories about a 'Dutch dip' in public trust and numerous ethical scandals that were revealed within politics and the public service. In managerial areas, however, the Dutch were mostly positive about the quality compared to five years ago (Van de Walle, Jilke \& van Delft). In Germany, managerial aspects of reform were also most positively assessed, with a majority of respondents seeing improvements in service quality, innovation and cost and efficiency. In policy-related fields, there was more sense of deterioration, with overall negative assessments of citizen trust in government, policy coherence and coordination, social cohesion and policy effectiveness.

In France, most reform outcomes were rated rather negatively, with cost and efficiency and innovation being seen as most improved. In contrast, it was felt that social cohesion and citizen trust in government had declined the most, but citizen participation, staff motivation, attractiveness of the public sector as an employer and cutting of red tape were also seen to deteriorate. Views on most of these issues were more favourable for executives from the economic and financial sectors, especially as regards quality of service. In Hungary, ethical behaviour among officials was seen to be most improved, but this figure was still significantly below the European average. In general, Hungarian attitudes towards improvement were below the European average, with the least 
improvement seen in areas such as attractiveness of the public sector as an employer, citizen trust in government and the cutting of red tape.

Although the Spanish case was the most pessimistic compared to five years ago, there were certain areas where greater improvement was perceived. Ethical behaviour of civil servants, equal access to services and fair treatment of citizens were perceived as relatively improved, and service quality, innovation and transparency and openness also had some positive perceptions. However, over half felt that citizens' trust in government had deteriorated, and public sector motivation and desirability as an employer were also perceived negatively. The perception of the public sector as an employer was actually more positive than the European average.

\section{Impact of the Fiscal Crisis}

The financial crisis that has gripped Europe starting in 2008 has had an impact on the nature of the public sector and its reform in the countries under study. Only Norway was a significant outlier and barely affected by the financial crisis. Therefore, a majority of respondents felt no cost-cutting measures were required. The nature of cuts differs across countries and can be assessed both in where these cuts took place and the way in which they were instituted. At an organisational level, most cutbacks in Estonia were realised through personnel savings. It was felt that the largest proportion of the cuts was done across all areas, whereas a somewhat smaller proportion of cutbacks was achieved through targeted cuts. The opposite was true in the Netherlands, where a somewhat higher proportion felt cuts were targeted, but a significant proportion still felt that cuts were across the board. Most cuts in that country came about through hiring freezes and cuts to programmes. In France, a main effect of the crisis has been an adjustment of public servants' benefits downwards to come into line with the private sector, along with a hiring freeze. There was no clear consensus on the nature of these cuts, with almost equal numbers feeling they were acrossthe-board, targeted or achieved through productivity gains. However, staff cuts and pay cuts are seen as unimportant in France; although a hiring freeze was in place, this did not result in cutting of staff. Meanwhile, there was a feeling that the budget crisis had increased the powers of the Ministry of Finance and centralized decision-making.

UK reforms in public administration were greatly affected by the downturn, which hit the country significantly. The current coalition government has made large cuts to the public sector as a response to the crisis. A majority of respondents felt that these cuts were targeted, but over one quarter felt these cuts were across the board and almost $20 \%$ felt they were efficiency savings. In comparison to the rest of Europe, a larger proportion of UK executives saw some form of cutbacks and these cutbacks were more likely to be a result of pay freezes or staff cuts in the UK. The fiscal crisis also hit Spain hard, as they moved from above average growth rates to significant decline and unemployment. The cuts were perceived to be mostly targeted cuts, by a large majority. Proportional cuts across the board were the next largest perceived cut. Many of these savings came from cutting personnel costs, with hiring freezes, wage freezes and pay cuts being seen as the most significant, along with cuts to new and existing programmes. The fiscal crisis hit Italian public administration as well, but was somewhat mitigated by the fact that Italy had been trying to reign in public spending prior to the crisis. The most significant cuts were across the board, which were significantly higher than the European average, whereas targeted cuts and efficiency savings were lower than average. 
German public administration reform responses to the fiscal crisis have been evaluated as quite successful. Most executives responded that they had faced some sort of cutbacks. Compared to other countries, however, a much higher proportion saw these cuts as targeted, with fewer seeing across-the-board cuts. As in France, these cutbacks could not be realized through layoffs or even pay cuts, with savings brought about more through programme cuts and hiring freezes. Cutbacks in Hungary were fairly equally seen to be across-the-board and targeted, with mainly across-the-board cuts in delivering services, but targeted cuts at the ministerial level. Although the government in Hungary explains cutbacks as a move to make the public service more efficient, interestingly less than $2 \%$ of respondents felt that cuts came from productivity and efficiency savings. Hiring freezes were seen as the most-used approach to cost cutting, but staff cutbacks also represented a higherthan-average level of cost-cutting in Hungary compared to other European countries.

\section{Conclusions}

While public administration reforms - both NPM and post-NPM types - have taken place in all the countries under study in Europe, the nature and extent of these reforms vary greatly. Some of these differences follow traditional European North/South and East/West divides, but especially since the fall of communism and the rapid extension of the EU this has become more blurred. Even more interestingly, the perceptions by those undertaking the reforms of justification, nature and success of these reforms do not split along traditional lines.

The countries can be divided along the lines of NPM/post-NPM-style reforms, as well as the level of success of these reforms. In the Netherlands, Norway and Estonia, reforms were mostly seen as positive, and often followed an NPM-like trajectory. The UK was the only country that followed an NPM trajectory but had negative views about these reforms. Other countries focused more heavily on post-NPM reforms, or had few reforms overall along NPM lines. Some of these still felt the reforms were successful, such as Hungary and to a lesser extent Germany, while others - most notably France and Spain and to a lesser extent Austria - had overall negative views of reform that has taken place (Hammerschmid et al., 2013a).

\begin{tabular}{|l|l|l|}
\hline Positive View of Reform & NPM-Style Reforms & Non-NPM-Style Reforms \\
\hline $\begin{array}{l}\text { Estonia } \\
\text { Netherlands } \\
\text { Norway }\end{array}$ & $\begin{array}{l}\text { Hungary } \\
\text { Germany }\end{array}$ \\
\hline United Kingdom & Unative Review of Reform & $\begin{array}{l}\text { Austria } \\
\text { France } \\
\text { Spain } \\
\text { Italy }\end{array}$ \\
\hline
\end{tabular}

Some conclusions can be drawn from the above results. First, context does matter, as there is some differentiation based on the starting points of each country. However, this is not as strong an indicator of types of reform as might be expected. Countries with a Napoleonic tradition of public administration tended to fare poorly in implementing NPM-style reforms and have a negative view towards these reforms, but other groupings were less clear-cut. While the UK has the longest and strongest history of NPM-style public administration, it had a negative view of reforms undertaken, which could possibly be a result of its longer history with NPM. The two eastern-bloc cases under 
consideration - Hungary and Estonia - have responded differently after their democratic transition and entry into the EU, with Estonia embracing NPM-style public administration, whereas Hungarian reform has been more reticent to adopt these processes. However, both countries saw any reform that took place as positive. The different clusters presented by this research point to the great reforms undertaken in the past twenty years (and even in the past five) and the fact that these reforms, while sometimes having an NPM-style base, have gone on different trajectories that do not always follow public administration traditions.

Second, to a great degree reforms depend on public sector autonomy and politicisation. Autonomy was high and politicisation low in countries such as the Netherlands, the UK and Norway, but comparatively low in Spain and Italy. While it was not perfectly correlated, in general those with higher autonomy and less politicisation perceived reforms as being more successful. The level of goal ambiguity had a less clear effect on the relative success as reforms, as all countries perceived their goals to be more ambiguous than not, with less cross-country difference.

Third, in almost all countries under study, NPM-type reforms such as contracting out or agencification have become less important in the past five years, often supplanted by post-NPM style reforms based on e-government, transparency, citizen engagement and coordination. Privatisation was seen as the least important trend, but some NPM-style reforms remained important, such as a focus on outcomes and results and treating citizens as customers.

There was a significant level of cross-country agreement on the nature of these reforms. All countries perceived these reforms as coming from the top down, and all countries apart from Norway felt these reforms were undertaken to cut costs rather than to improve services. Likewise, all countries apart from Norway and Hungary feel that these reforms were done with little public involvement. There was less cross-country consensus on factors such as whether these reforms were mainly driven by politicians or senior executives, or whether these reforms were contested by unions.

Countries were split on whether reforms - regardless of their type or dynamic - were successful or not, and there was no clear pattern determining this perception of improvement or deterioration. There was no significant variation on different dimensions of success either, with the average perception of most executives being clustered around a neutral view indicating neither success nor failure. Cost and efficiency, service quality, transparency and openness, innovation and fair treatment of citizens were rated relatively positively, but worryingly, citizen trust in government was seen to have deteriorated the most in the past five years.

Finally, the financial crisis has been seen as an impetus for reform in recent years in all countries apart from Norway. It has not hit the countries to the same extent, and strategies for cost cutting have differed across countries, but few feel that it has not affected reform. Taken together, these factors illustrate the complexity of public service reform in Europe and the forms it may take. In some aspects, it also shows a lack of consensus on what reforms are necessary, what dynamic they have taken and whether they have been a success. While there is some convergence about the importance of factors such as e-government and collaboration, in other areas countries are split on the most important reforms to take place, and this convergence is also reflected in the reforms that have taken place, and their perceived success. However, there seems to be relatively clear consensus that public administration has moved beyond a straightforward NPM alignment (if such a 
thing ever existed in the first place) and has begun to embrace post-NPM reforms in response to some of the challenges and differences the continent has faced.

\section{$\underline{\text { References }}$}

Alonso, J. and Clifton, J. (2013). 'Public Sector Reform in Spain: Views and Experiences from Senior Executives.' COCOPS Work Package 3 Country Report.

Andrews, R., Downe, J. and Guarneros-Meza, V. (2013). 'Public Sector Reform in the UK: Views and Experiences from Senior Executives.' COCOPS Work Package 3 Country Report.

Bezes, P. and Jeannot, G. (2013). 'Public Sector Reform in France: Views and Experiences from Senior Executives.' COCOPS Work Package 3 Country Report.

Bouckaert, G., Halligan, J. (2008). Managing Performance: International Comparisons. Routledge, Taylor \& Francis.

Christensen, T. (2003). Narrative of Norwegian Governance: Elaborating the Strong State,"Public Administration ,81(1): 163-190.

Christensen, T. and P. Lægreid (2011). Complexity and hybrid public administration - Theoretical and empirical challenges, Public Organization Review, 11(4):407-423.

Christensen, T., A. Lie and P. Lægreid (2007). Still Fragmented or Reassertion of the Centre? In T.Christensen and P.Lægreid (eds.), Transcending New Public Management. Aldershot: Ashgate, pp.17-42.

Dunleavy, P., Margetts, H., Bastow, S. and J. Tinkler (2006): New Public Management is Dead - Long Live Digital-Era Governance. Journal of Public Administration Theory and Practice, 16(3): 467-494.

Fimreite, A.L. and P. Lægreid (2009). Reorganization of the Welfare State Administration: Partnerships, networks and accountability . Public Management Review, 11 (3): 281-297.

Hajnal, G. (2010). 'Failing Policies or Failing Politicians? Policy Failures in Hungary'. World Political Science Review 6:1, Article 13.

Hajnal, G. (2013). 'Public Sector Reform in Hungary: Views and Experiences from Senior Executives.' COCOPS Work Package 3 Country Report.

Hammerschmid, G. and R.E. Meyer (2005). 'New Public Management in Austria: Local Variation on a Global Theme?.' Public Administration, 83(3): pp. 709-733.

Hammeschmid, G., Van de Walle, S., Andrews, R., Bezes, P., Görnitz, G., Oprisor, A. and Štimac, V. (2013a). 'Public Administration Reform in Europe - Views and Experiences from Senior Executives in 10 Countries'. COCOPS Work Package 3 Cross-National Report.

Hammerschmid, G., Görnitz, A., Oprisor, A. and Štimac, V. (2013b). 'Public Sector Reform in Germany: Views and Experiences from Senior Executives.' COCOPS Work Package 3 Country Report.

Hammerschmid, A., Oprisor, A. and Štimac, V. (2013). 'COCOPS Executive Survey on Public Sector Reform in Europe: Research Report' COCOPS Work Package 3 Report.

Jann, W. (2003). 'Administration and Governance in Germany: Competing Traditions and Dominant Narratives.' Public Administration, 81(1): pp. 95-118.

Lægreid, P., Dyrnes Nord $\varnothing, \AA ̊$ and Rykkja, L. (2013). 'Public Sector Reform in Norway: Views and Experiences from Senior Executives.' COCOPS Work Package 3 Country Report. 
Luts, M., Delbeke, K., Hondeghem, A. \& Bouckaert, G. (2008). 'De efficiënte overheid geanalyseerd: Synthese \& aanbevelingen.' SBOV II Synthesis Report. Leuven: Bestuurlijke Organisatie Vlaanderen.

Meyer-Sahling, J.-H. (2011). The Durability of EU Civil Service Policy in Central and Eastern Europe after Accession. Governance, 24(2), 231-260.

O'Leary, R. and Blongren Bingham, L. (eds)(2009): The Collaborative Public Manager: New Ideas for the Twenty-First Century. Washington, DC: Georgetown University Press.

Ongaro, Edoardo (2009): Public management reform and modernization: trajectories of administrative change in Italy, France, Greece, Portugal and Spain. Cheltenham: Edward Elgar.

Ongaro, E., Ferré, F., Galli, D. and Longo, F. (2013). 'Public Sector Reform in Italy: Views and Experiences from Senior Executives.' COCOPS Work Package 3 Country Report.'

Pollitt, C. and Bouckaert, G. (2011). Public Management Reform: A Comparative Analysis. Oxford: Oxford University Press.

Rainy, Hal; Jung, Chun Su (2010): Extending goal ambiguity research in government: from organizational goal ambiguity to programme goal ambiguity. In Richard M. Walker, George A. Boyne, Gene A. Brewer (Eds.): Public Management and Performance. Research directions. Cambridge, New York: Cambridge University Press, pp. 34-59.

Randma-Liiv, T. (2002). Small States and Bureaucracy: Challenges for Public Administration. Trames, 6(4), 374 - 389.

Rouban, L. (2008). 'Reform Without Doctrine: Public Management in France.' International Journal of Public Sector Management, 21(2): pp. 133-149.

Savi, R. and Metsma, M. (2013). 'Public Sector Reform in Estonia: Views and Experiences from Senior Executives.' COCOPS Work Package 3 Country Report.

Torres, L. and V. Pina (2004) . 'Reshaping Public Administration: The Spanish Experience Compared to the UK'. Public Administration, 82(2):445-464.

Van de Walle, S., Jilke, S. and van Delft, R. (2013). 'Public Sector Reform in the Netherlands: Views and Experiences from Senior Executives.' COCOPS Work Package 3 Country Report.

Van Twist, M., Van der Steen, M, Karré, P.M., Peeters, R. \& Van Ostaijen, M. (2009). Vernieuwende verandering: continuiteit en discontinuiteit van vernieuwing van de rijksdienst. Den Haag: NSOB. 